\title{
Physiological quality and dry mass production of Sorghum bicolor following silicon (Si) foliar application
}

\author{
Rilner Alves Flores ${ }^{1 *}$, Everton Martins Arruda ${ }^{2}$, Virgínia Damin ${ }^{1}$, Jonas Pereira Souza Junior ${ }^{3}$, Deyvid Diego \\ Carvalho Maranhão ${ }^{4}$, Marcus André Ribeiro Correia ${ }^{5}$, Renato de Mello Prado ${ }^{3}$
}

${ }^{1}$ Soil Sector, Agronomy School, Federal University of Goiás, Goiânia, Brazil

${ }^{2}$ University of the State of Mato Grosso, Campus of Nova Mutum, Nova Mutum, Brazil

${ }^{3}$ Department of Soil and Fertilizers, Paulista State University, Jaboticabal, Brazil

${ }^{4}$ Department of Soil Science, Rural Federal University of Rio de Janeiro, Seropédica, Brazil

${ }^{5}$ Federal Institute of Tocantins, Campus of Colinas do Tocantins, Colinas do Tocantins, Brazil

* Corresponding author: rilner1@hotmail.com

\begin{abstract}
The forthcoming of silicon (Si) highly soluble sources provided a suitable alternative to Si use in agroecosystems. There are many benefits associated to Si application in crops, such as improvement in feed quality. In this sense, the aim of this work was to evaluate the effect of Si foliar application on physiological quality, biomass production, and silicon accumulation in Sorghum bicolor. The experiment was conducted under greenhouse condition using an entirely randomized design, with five Si rates $(0$ as control), $0.84,1.68,2.52$, and $3.36 \mathrm{~g} \mathrm{~L}^{-1}$ of Si) applied as potassium and sodium silicate, with four repetitions. In each treatment, applied solutions were balanced in potassium in order to isolate the Si effect. The following measurements were taken: growth, biomass production, Si accumulation, and physiological quality. Supplying Si via leaves did not affect the sorghum growth rate and the relative chlorophyll index; however, leaf area increased $23 \%$ with the use of $2.36 \mathrm{~g} \mathrm{~L}^{-1}$ of Si. Physiological variables are influenced by increasing $\mathrm{Si}$ rates, with rates close to $1.68 \mathrm{~g} \mathrm{~L}^{-1}$ of $\mathrm{Si}$ causing the best photosynthetic rates and stomatal conductance. The use of potassium silicate as a source of silicon is an alternative for productivity increases up to $30 \%$, but an economic study on the viability of its commercial application in the production chain of Sorghum bicolor is necessary.
\end{abstract}

Keywords: Silicon fertilization; beneficial element; mineral plant nutrition; photosynthesis; stomata conductance; relative chlorophyll index; transpiration.

Abbreviations: Si_Silicon; $\mathrm{pH} \_$hydrogen potential; Al_aluminum; P_phosphorus; K_potassium; Mg_magnesium; $\mathrm{SO}_{4}{ }_{4}^{2-}$ sulfate; Zn_zinc; B_boron; H_hydrogen; CEC_cation exchange capacity; V\%_base saturation; ERD_randomized experimental design; MAP_monoammonium phosphate; $\mathrm{KCl}_{-}$potassium chloride; PRNT_relative total neutralization power; DAE_days after emergence; $\mathrm{RCl}$ _relative chlorophyll index; DAS_days after sowing; IRGA_system portable infrared gas analyzer; PPFD_density of photon flux; ABef_nutritional indices comprising absorption efficiency; UTef_efficiency of use of nutrients for conversion to dry matter.

Introduction

Sorghum (Sorghum bicolor) is currently considered to be the fifth most important grain for use as food, fiber production, and energy (Zheng et al., 2011). The crop stands out for presenting satisfactory grain and biomass productivity in regions that are considered unproductive for other cereals because they are very warm and/or dry, with annual precipitation between 375 and $625 \mathrm{~mm}$ (Ribas, 2003). In the last decade, total production was 60 million tons in an area of 44 million hectares (Zheng et al., 2011).

Sorghum can be cultivated in conditions that are adverse to other crops, however the management strategies aiming reduce the deleterious effect of drying is important to guarantee a suitable production. In this sense, silicon (Si) application can be performed, since it may increase the plant's tolerance to elevated temperatures (Okamoto, 1969; Soundararajan et al., 2014), hydric deficit (Lux et al., 2002;
Hattori et al., 2005), Mg toxicity (Galvez et al., 1987) e Al toxicity (Cocker et al., 1998) and salinity (Kafi and Rahimi, 2011). Silicon is absorbed by sorghum as opaline silicon (phytolites), increasing the growth rates and, therefore, crop production. Moreover, some quality improvements and protection to abiotic and biotic stress have been associated with Si application (Tripathi et al., 2013). When absorbed, Si leads to the formation of a double layer of silica-cuticle and silica-cellulose in the cellular wall, giving to the plants physical resistance and reducing transpiration, resulting in an increase in water use efficiency (Ma and Yamaji, 2006; Barbosa Filho et al., 2001). Silicon accumulation in leaves can reduces the salt accumulation and the plasmatic membranes permeability, maintaining their integrity and functioning through a decrease in lipid peroxidation and an increase in superoxide dismutase activity (Matoh et al., 1986; Zhu et al., 
2004). In dry soil, Si acts maintaining the photosynthetic rate and stomatal conductance of plants, keeping them at high levels (Gong et al., 2008). Moreover, $\mathrm{Si}$ is also indicated to increase antioxidant defense capacity (Zhu et al., 2004). The element thus gives plants greater tolerance to hydric deficit. The positive effect of Si application may is related with the accumulation of large Si amounts in the endoderm tissues of sorghum, increasing the crop tolerance to the stress (Lux et al., 2002), since endoderm cells have an important role in water transportation by roots (Steudel and Peterson, 1998). Moreover, silicon increases membrane permeability in sorghum roots (Hattori et al., 2003). Silicon has fast absorption and deposition in sorghum (Lux et al., 2003), favoring water transport and/or root growth in stress condition. The silicate use incorporated into the soil requires high rates, moreover polymerization reactions may occur in the soil, decreasing its availability (Carvalho et al., 2009). The emergence of highly soluble sources can make the Si use in different crops viable and reinforce the sustainability of agriculture, especially in the case of forage grasses that produce biomass for animal feed, such as forage sorghum.

The use of highly soluble foliar $\mathrm{Si}$, in stabilized form and in small rates can improve the nutritional and physiological plant's state, as well as reducing phytosanitary problems and promoting gains in productivity. The silicon application in stabilized form is an alternative in cropping systems, since it has showed some benefits to crops development and production mainly under stress conditions (Crusciol et al., 2013). In this source, silicon is applied as stabilized silicic acid, and after dissolution form orthosilic acid, which may increase Si absorption by plants (Sorato et al., 2012).

The Si application has been show some increase in Si foliar in wheat and white oat, following an increase in roots lengh of aot and in seeds dry mass of wheat (Toledo et al., 2012). Assuming that foliar Si application using a source with high solubility can result in higher Si fertilization efficiency, the aim of this study was to evaluate the effect of leaf-applied silicon on physiological quality, biomass production, and silicon accumulation in Sorghum bicolor.

\section{Results}

\section{Height, leaf area and Relative chlorophyll index $-\mathrm{RCI}$}

Increasing Si application rates did not affect height and relative chlorophyll index $(\mathrm{RCl})$ of sorghum plants; however, leaf area was linearly increased (Table 1 ). The highest leaf area $\left(642.71 \mathrm{~cm}^{2}\right)$ was obtained with the rate of $3.36 \mathrm{~g} \mathrm{~L}^{-1}$ of $\mathrm{Si}$; that is $23 \%$ higher compared to control, which was 518.64 $\mathrm{cm}^{2}$ (Fig. 1).

\section{Physiological quality}

The physiological parameters of Sorghum bicolor plants were affected by increasing $\mathrm{Si}$ rates application, with exception of transpiration rates, which was not affected by Si supply, presenting an average of $0.21 \mathrm{mmol} \mathrm{m}^{-2} \mathrm{~s}^{-1}$ (Table 2). Stomatal conductance presented a quadratic response, with the highest value $\left(4.71 \mathrm{mmol} \mathrm{m}^{-2} \mathrm{~s}^{-1}\right)$ obtained with the use of $1.96 \mathrm{~g} \mathrm{~L}^{-1}$ of $\mathrm{Si}$ (Fig. 2). With the reduction in stomatal opening caused by an increased supply of $\mathrm{Si}$, the internal concentration of $\mathrm{CO}_{2}$ is also affected (Fig. 3), decreasing by approximately $8 \%$ (429.66 ppm) when the highest Si rate was applied, in relation to the control treatment (467.03 ppm). Net photosynthesis rate also presented a quadratic behavior, with an increase being observed up to the rate of $2.03 \mathrm{~g} \mathrm{~L}^{-1}$, which provided a net photosynthesis rate of 3.06 $\mu \mathrm{mol} \mathrm{m} \mathrm{s}^{-1}$ (Fig. 4).

\section{Dry mass}

Increasing Si rates were observed linear increases in dry mass production of roots, aerial part and entire plant (Table 3 , Fig 5). It was noted that the increase in biomass production with the highest rate $\left(3.36 \mathrm{~g} \mathrm{~L}^{-1}\right.$ ) was 19 (aerial part), 80 (roots), and $31 \%$ (entire plants) higher than observed in the control treatment (without applying $\mathrm{Si}$ ), which produced was $14,3.36$, and $17.36 \mathrm{~g} \mathrm{plant}^{-1}$ in aboveground part, root, and entire plant, respectively (Fig. 5).

\section{Accumulation and efficiency}

Silicon accumulation in all plant's part, and efficiencies of utilization and absorption were affected by increasing Si rates application (Table 4). A positive linear response was observed in Si accumulation in all plant's part, reaching 246, 314 , and $257 \%$ more Si accumulation in relation to the control treatment (without applying $\mathrm{Si}$ ) in the aboveground part, root, and entire plant, respectively (Fig. 6). The Si accumulation in roots probably indicating the $\mathrm{Si}$ redistribution from leaves to the roots though the phloem (Table 4). The absorption and utilization efficiencies presented contrasting behavior; that is, there was an increase in $\mathrm{Si}$ absorption efficiency by the plant with a greater supply of it, whereas the utilization efficiency decreased (Table 4). It was noted that absorption efficiency presented a quadratic response, reaching $12.12 \mathrm{mg} \mathrm{g}^{-1}$ with application of $3.13 \mathrm{~g} \mathrm{~L}^{-1}$ of $\mathrm{Si}$. On the other hand, the utilization efficiency by sorghum plants was reduced, practically halting the rate of dry material conversion, and reaching levels close to null (Fig. 7).

\section{Discussion}

\section{Biometric variables}

Sorghum plants height and the relative chlorophyll index $(\mathrm{RCl})$ were not affected by $\mathrm{Si}$ application rates. These results support Yin et al. (2013) in studies involving the Si application to mitigate the detrimental effect of salinity in sorghum, and Cessa et al. (2011) in studies involving different $\mathrm{P}$ and $\mathrm{Si}$ rates in sorghum. In these studies, both authors verified that Si did not affect the plants' vegetative growth under normal cultivation conditions. Regarding leaf area, there was a linear increase after increasing Si rates application. Similarly, Gong et al. (2003) verified that even in adequate cultivation conditions, Si resulted in an increase in leaf area for wheat.

\section{Physiological quality}

Silicon rates affected stomatal conductance, which is due to the fact that $\mathrm{Si}$ accumulates in large quantities in the stomas and guard cells, forming a silica double layer, resulting in a 
Table 1. Leaf area, height, relative chlorophyll index $(\mathrm{RCl})$, of Sorghum bicolor fertilized with increasing silicon rates.

\begin{tabular}{lccccc}
\hline Rates & Leaf area & Height & $\mathrm{RCl}^{1}$ & $\mathrm{RCl}^{2}$ & $\mathrm{RCl}^{3}$ \\
\hline $\mathrm{g} \mathrm{L}^{-1}$ & $\mathrm{~cm}^{2}$ & $\mathrm{~cm}$ & ---14 & 46.04 & 38.34 \\
0 & 518.64 & 88.00 & 33.14 & 44.86 & 40.55 \\
0.84 & 527.27 & 89.75 & 34.19 & 43.34 & 39.95 \\
1.64 & 565.09 & 90.25 & 33.89 & 46.51 & 40.40 \\
2.52 & 625.56 & 97.62 & 34.43 & 38.76 \\
3.36 & 642.71 & 97.75 & 32.31 & 45.45 & $\mathrm{~ns}$ \\
\hline Test F & $* *$ & ns & ns & 6.68 & 5.56 \\
C.V. (\%) & 8.15 & 8.34 & 6.65 & ns
\end{tabular}

$\mathrm{RCl}^{1}, \mathrm{RCl}^{2}$ and $\mathrm{RCl}{ }^{3}$ - evaluations of relative chlorophyll index at 15,30 and 45 days after the emergency (DAE). C.V. - Coefficient of variation. ${ }^{* *}$ and ${ }^{\mathrm{ns}}$ - significant at $1 \%$ and not significant at $5 \%$ of probability by the $F$ test, respectively.

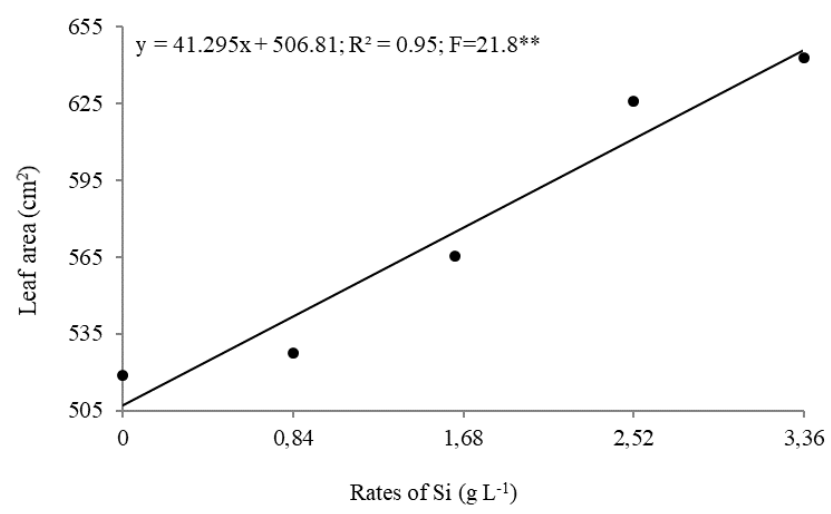

Fig 1. Leaf area of Sorghum bicolor fertilized with increasing silicon rates. ${ }^{*}$ Significant at $1 \%$ of probability by the $\mathrm{F}$ test.

Table 2. Physiological variables of Sorghum bicolor fertilized with increasing silicon rates.

\begin{tabular}{lcccc}
\hline Rates & $\begin{array}{c}\text { Stomatal } \\
\text { conductance }\end{array}$ & $\begin{array}{c}\text { Liquid } \\
\text { photosynthesis }\end{array}$ & Transpiration & Internal concentration of $\mathrm{CO}_{2}$ \\
\hline $\mathrm{g} \mathrm{L}^{-1}$ & $\mathrm{mmol} \mathrm{m}^{2} \mathrm{~s}^{-1}$ & $\mu \mathrm{mol} \mathrm{m}^{2} \mathrm{~s}^{-1}$ & $\mathrm{mmol} \mathrm{m}^{2} \mathrm{~s}^{-1}$ & $\mathrm{ppm}$ \\
0 & 3.02 & 0.25 & 0.25 & 463.52 \\
0.84 & 3.99 & 1.51 & 0.22 & 461.17 \\
1.64 & 4.97 & 4.01 & 0.20 & 452.80 \\
2.52 & 4.32 & 2.06 & 0.21 & 439.77 \\
3.36 & 3.91 & 2.07 & 0.18 & 430.26 \\
\hline Test F & $* *$ & $* *$ & $\mathrm{~ns}$ & $*$ \\
C.V. (\%) & 10.70 & 32.43 & 28.94 & 2.03 \\
\hline
\end{tabular}

C.V. - Coefficient of variation. ${ }^{* *}$ and ${ }^{\mathrm{ns}}$ Significant at $1 \%$ and not significant at $5 \%$ of probability by the $\mathrm{F}$ test, respectively.

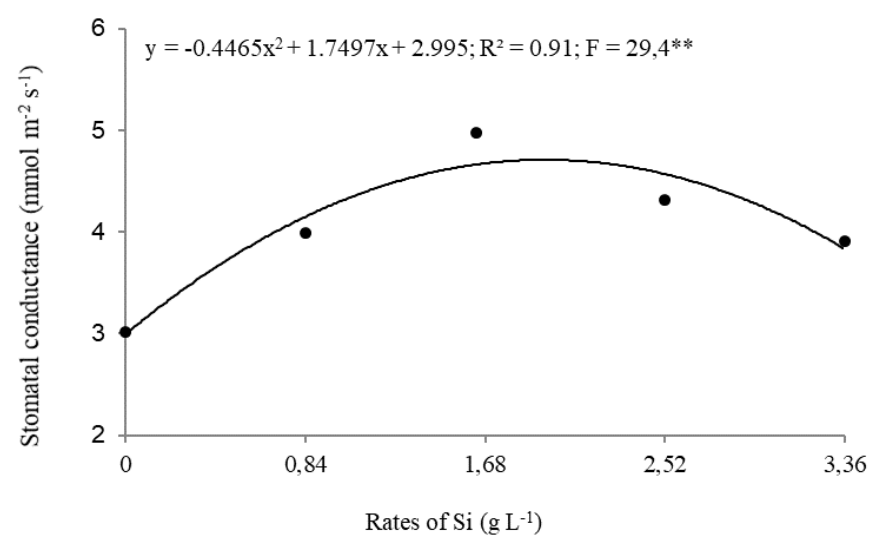

Fig 2. Stomatal conductance of Sorghum bicolor fertilized with increasing silicon rates. ${ }^{* *}$ Significant at $1 \%$ of probability by the $\mathrm{F}$ test. 
Table 3. Dry mass of aboveground part (DMAP), roots (DMR) and entire plant (DMEP) of Sorghum bicolor fertilized with increasing silicon rates.

\begin{tabular}{|c|c|c|c|}
\hline Rates & DMAP & DMR & DMEP \\
\hline $\mathrm{g} \mathrm{L}^{-1}$ & ------ & plant $^{-1}$ & -- \\
\hline 0 & 14.00 & 3.50 & 17.50 \\
\hline 0.84 & 14.75 & 4.00 & 18.75 \\
\hline 1.64 & 15.25 & 4.50 & 19.75 \\
\hline 2.52 & 15.75 & 5.25 & 21.00 \\
\hline 3.36 & 16.75 & 6.25 & 23.00 \\
\hline Test F & $* *$ & $* *$ & $* *$ \\
\hline C.V. (\%) & 4.46 & 12.88 & 3.29 \\
\hline
\end{tabular}

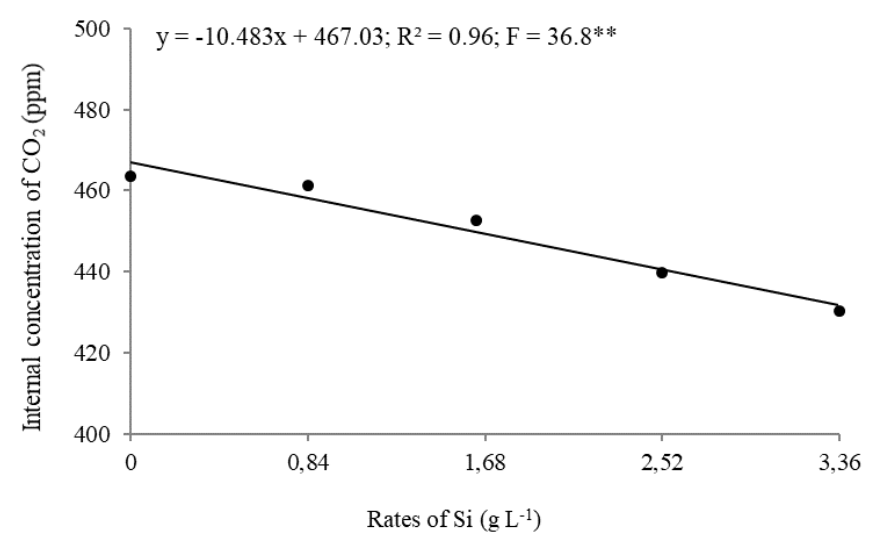

Fig 3. Internal concentration of $\mathrm{CO}_{2}$ de Sorghum bicolor fertilized with increasing silicon rates. ${ }^{* *}$ Significant at $1 \%$ of probability by the $F$ test.

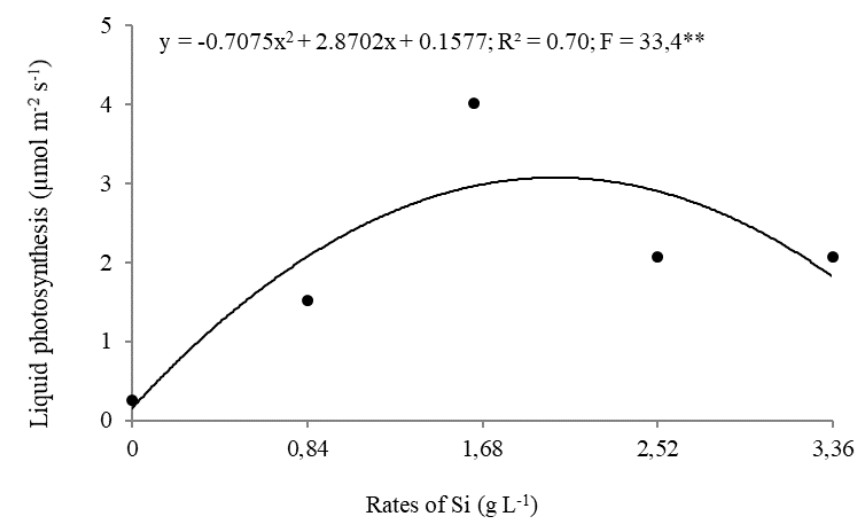

Fig 4. Liquid photosynthesis of Sorghum bicolor fertilized with increasing silicon rates. ${ }^{* *}$ Significant at $1 \%$ of probability by the $\mathrm{F}$ test.

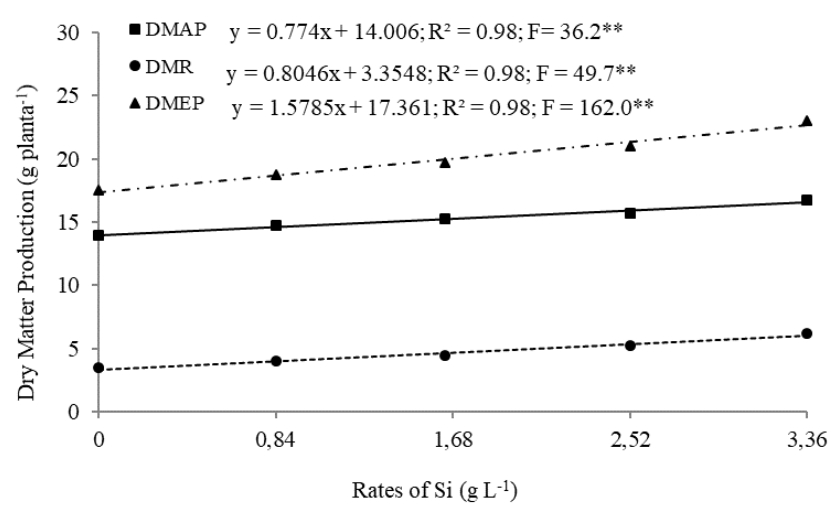

Fig 5. Dry mass of aboveground part (DMAP), roots (DMR) and entire plant (DMEP) of Sorghum bicolor fertilized with increasing silicon rates. ${ }^{* *}$ Significant at $1 \%$ of probability by the $\mathrm{F}$ test. 


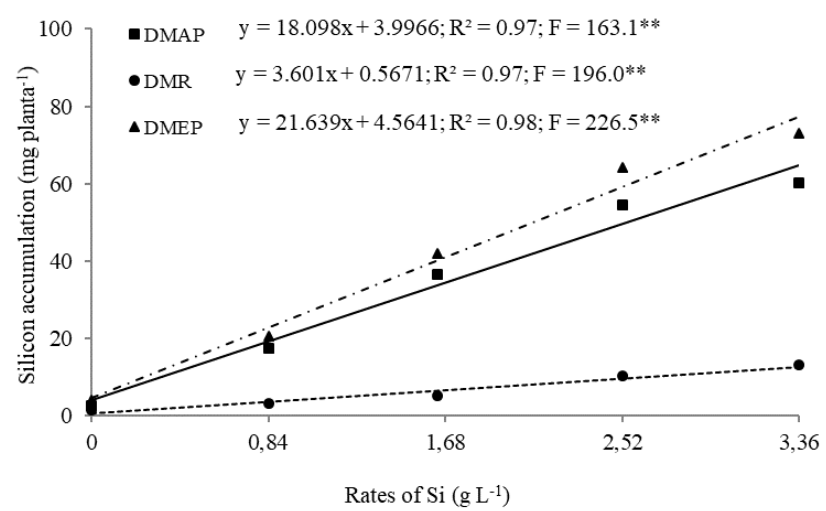

Fig 6. Silicon accumulation of aboveground part (DMAP), roots (DMR) and entire plant (DMEP) of Sorghum bicolor fertilized with increasing silicon rates. ${ }^{* *}$ Significant at $1 \%$ of probability by the $\mathrm{F}$ test.

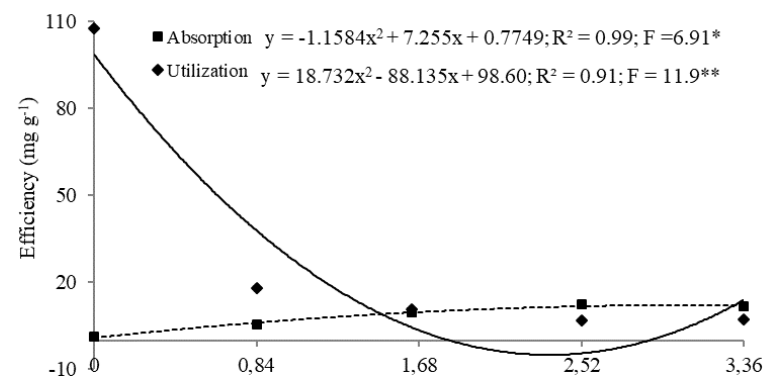

Rates of $\mathrm{Si}\left(\mathrm{g} \mathrm{L}^{-1}\right)$

Fig 7. Efficiency of absorption $\left(\mathrm{AB}_{\mathrm{ef}}\right)$ and utilization $\left(\mathrm{UT}_{\mathrm{ef}}\right)$ of silicon of Sorghum bicolor fertilized with increasing silicon rates.

** and $*$ Significant at 1 and $5 \%$ of probability by the $\mathrm{F}$ test, respectively.

smaller stomatal opening (Oliveira and Castro, 2002), and as a consequence reducing stomatal conductance. The increase in net photosynthesis rate with the Si supply may be associated with the more efficient use of water, which results in a higher photosynthetic rate (Ma and Yamaji, 2006). However, one possible explanation for the fall in the net photosynthesis rate with increased $\mathrm{Si}$ rates is that accumulation in the guard cells results in decreased stomatal conductance. The internal $\mathrm{CO}_{2}$ concentration, which is the substrate for photosynthesis, thus decreases in the leaf.

\section{Dry mass}

Following Si application, sorghum plants under hydric stress showed an increase in the leaf area and in specific leaves weight. Increases in chlorophyll and aboveground, roots and entire plant's dry mass were also observed, suggesting an increase in sorghum stress resistance (Ahmed, Qadeer and Aslan, 2011). This fact crop is mainly important in tropical regions, where crops show higher evapotranspiration. In recent literature, some papers report increases in biomass production in grasses after increasing Si supply (Korndorfer et al., 2001; Fonseca et al., 2009; Sávio et al., 2011).

The dry mass increase has no correlation with potassium supply, since the same amount of $\mathrm{K}$ was applied in all treatments (potassium chlorite was used to equilibrate $\mathrm{K}$ concentration after application of increasing doses of potassium silicate), as explained in material and methods section. The use of potassium silicate as a source of silica is an alternative for increase productivity up to $30 \%$, but an economic study of the economic viability of commercial application in the production chain of Sorghum bicolor is necessary.

\section{Accumulation and Efficiency}

Similarly to observed in the present work, there are various reports in the literature that $\mathrm{Si}$ accumulation increases when plants are supplied with $\mathrm{Si}$, starting with accumulation in the roots and passing through the leaf sheaths to the leaf lamina (Kahn et al., 2016); however, when Si is applied on soil.

With increased rates of $\mathrm{Si}$, an increase in the accumulation of $\mathrm{Si}$ occurs in the roots, probably indicating the redistribution of $\mathrm{Si}$ applied to the leaf via phloem to the roots (Table 4). Redistribution is defined as the movement of an element from one place to any other organ (Malavolta, 2006) and is directly linked to the element mobility in phloem (Hocking, 1980). Si is considered an immobile element since Si redistribution in the plant is not significant (Santos et al. 2012; Alves et al., 2014); however, the presence of sorbitol may have resulted in a soluble compound with greater mobility in phloem. Sorbitol is a polyol with a moistening action, which delays the solution from drying by lowering the point of eliquescence in the formulation of the leaf, prolonging the absorption process (Will et al., 2011). Studies have also shown that the interaction between sorbitol and some nutrients, such as B, 
can result in greater mobility of it within the phloem in plants that produce polyols naturally (Brown and $\mathrm{Hu}, 1998$ ).

\section{Materials and methods}

\section{Experimental area}

The study was conducted under greenhouse condition at the School of Agronomy of the Federal University of Goiás, in Goiás State, Brazil, at the coordinates $16^{\circ} 35^{\prime \prime}$ south latitude and $49^{\circ} 21^{\prime \prime}$ west longitude. The region's climate is the Aw (Megathermal) or savanna tropical climatic type, with dry winters and rainy summers, according to the Köppen classification. The altitude is approximately $730 \mathrm{~m}$ and the average annual precipitation is $1600 \mathrm{~mm}$.

Each experimental unit was comprised of a $4 \mathrm{dm}^{3}$ capacity pot, filled with $3.5 \mathrm{dm}^{3}$ of samples from a 0-20 cm deep superficial layer of Rhodic Hapludox (Soil Survey Staff, 2014). The initial chemical analysis of the soil presented the following attributes: $\mathrm{pH}: 4.4\left(\mathrm{CaCl}_{2}\right) ; \mathrm{Al}^{3+}: 0.5 \mathrm{cmol}_{\mathrm{c}} \mathrm{dm}^{-3}$; organic material: $2.3 \mathrm{~g} \mathrm{dm}^{-3}$; P: $0.8 \mathrm{mg} \mathrm{dm}^{-3} ; \mathrm{K}^{+}: 25 \mathrm{mg} \mathrm{dm}^{-3}$; $\mathrm{Ca}^{2+}: 0.4 \mathrm{cmol}_{\mathrm{c}} \mathrm{dm}^{-3} ; \mathrm{Mg}^{2+}: 0.3 \mathrm{cmol}_{\mathrm{c}} \mathrm{dm}^{-3} ; \mathrm{SO}_{4}^{2-}: 5.6 \mathrm{mg} \mathrm{dm}$ ${ }^{3} ; \mathrm{Zn}^{2+}: 1.4 \mathrm{mg} \mathrm{dm}^{-3}$; B: $0.14 \mathrm{mg} \mathrm{dm}^{-3} ;\left(\mathrm{H}+\mathrm{Al}^{3+}\right): 1.27 \mathrm{cmol}_{\mathrm{c}}$ $\mathrm{dm}^{-3}$; cation exchange capacity (CEC): $2.03 \mathrm{cmol}_{\mathrm{c}} \mathrm{dm}^{-3}$; base saturation (V\%): $37.4 \%$. The granulometric analysis presented 530,180 , and $135 \mathrm{~g} \mathrm{~kg}^{-1}$ of clay, silt, and sand, respectively.

\section{Experimental design}

The treatments were arranged in an entirely randomized experimental design, with five foliar Si rates: T1 - $(0$ (control); T2 - 0.84; T3 - 1.68, T4 - 2.52, and T5 - 3.36 g L ${ }^{-1}$ of $\mathrm{Si}$ ), applied as potassium and sodium silicate ( $\mathrm{Si}=124 \mathrm{~g} \mathrm{~L}^{-1}$; $42 \mathrm{~g} \mathrm{~K}_{2} \mathrm{O} \mathrm{L}^{-1} ; 31 \mathrm{~g} \mathrm{Na}_{2} \mathrm{O} \mathrm{L}^{-1} ; \mathrm{d}=1.15 \mathrm{~g} \mathrm{~L}^{-1}$ ), with four repetitions. In each treatment containing silicon, the potassium content was balanced using potassium chloride, with T1 - 1.904; T2 - 1.428; T3-0.952; T4 -0.476 de $\mathrm{g} \mathrm{L}^{-1}$ of $\mathrm{KCl}$, and $\mathrm{T} 5$ - without applying $\mathrm{KCl}$.

\section{Experiment development}

Lime was applied as dolomitic limestone $(\mathrm{CaO}=36 \%$; $\mathrm{MgO}=15 \%$; $\mathrm{PN}=98 \%$; $\mathrm{PRNT}=92.54 \%$ ) to raise base saturation to $60 \%$. Soil humidity was corrected to $60 \%$ of the soil maximum capacity to water retention-MCWR) and pots were incubated for 30 days.

After this period, before planting, basic fertilization performed as a nutrient solution in rates equivalent to $80 \mathrm{~kg}$ ha $^{-1}$ of $\mathrm{P}_{2} \mathrm{O}_{5}$, using monoammonium phosphate (MAP) as $\mathrm{P}$ source; $60 \mathrm{~kg} \mathrm{ha}^{-1}$ of $\mathrm{K}_{2} \mathrm{O}$ as potassium chloride $(\mathrm{KCl})$; and 80 $\mathrm{kg} \mathrm{ha}^{-1}$ using urea as a source, $20 \mathrm{~kg} \mathrm{ha}^{-1}$ applied during planting and the rest $\left(60 \mathrm{~kg} \mathrm{ha}^{-1}\right) 30$ days after planting, in accordance with Sousa and Lobato (2004).

The BRS655 hybrid forage sorghum (Sorghum bicolor) was used for planting. Sowing was carried out on $29^{\text {th }}$ June, 2015. Ten days after seedlings emergence (DAE), thinning was performed and 2 plants were maintained per pot. Pots were irrigated daily with deionized water using the pot weighing method, keeping humidity at $60 \%$ of the MCWR.

Silicon application on plants was performed three times, being first of the Si rate applied at $15 \mathrm{DAE}$, second at $30 \mathrm{DAE}$, and third at the end of the vegetative state in pre-bloom (45
DAE). The volume of each application was calculated to cover the whole leaf area of the plant. Before each Si application, pots were covered with impermeable material to avoid the solution sprinkled onto the leaves seeping into the soil.

\section{Physiological parameters}

The relative chlorophyll index $(\mathrm{RCl})$ evaluations were performed 7 days after each Si application, using the third expanded leaf on each plant. A chlorophyll meter was used, ClorofiLOG CFL1030 model. When the forage grass was cut, 60 days after sowing (DAS), the shoots height and leaf area were taken, using a LI-3100 Area Meter equipment. The net photosynthesis rate and stomatal conductance were measured using an open system portable infrared gas analyzer (IRGA) model LICOR 6400, such as described by Santos Junior et al. (2006). The measurements were taken between 8 am and $3 \mathrm{pm}$ in totally extended leaves in good phytosanitary conditions. The photosynthetic variables response to the luminous intensity were determined for photon flux density (PPFD) of $550 \mu \mathrm{mol} \mathrm{m} \mathrm{m}^{-2}$ with the foliar chamber adjusted to operate with a $\mathrm{CO}_{2}$ concentration of $380 \pm 5 \mu \mathrm{mol} \mathrm{mol}^{-1}$, temperature of $31 \pm 1{ }^{\circ} \mathrm{C}$ and water vapor of $21 \pm 1 \mathrm{mmol} \mathrm{mol}^{-1}$ with leaf area of $1 \mathrm{~cm}^{2}$.

Thus, biomass production was evaluated, separating the aerial part from the roots. The vegetal tissue samples were washed with $0.1 \%$ detergent solution, $0.3 \%$ acidic solution, and distilled water, to decontaminate possible residues from the foliar applications. After that, plant materials were oven drying $\left(65^{\circ} \mathrm{C}, 48 \mathrm{hs}\right)$ and determining the aerial part and roots dry mass. In plant's tissues, the silicon level was determined in accordance with Korndörfer et al. (2004). Then the Si accumulation in the aerial part was calculated using leaf tissue Si content data, as well as the increase in dry mass.

Using the dry matter and nutrients content in plants data were performed the calculation of the nutritional indices comprising absorption efficiency (ABef) and efficiency of use of nutrients for conversion to dry matter (UTef) (Prado, 2008). These indices calculation were proceeded as following:

Equation Swiader et al. (1994):

$$
\mathrm{AB}_{\mathrm{ef}}=\frac{\text { total nutrient content in plant }}{\text { root dry matter }}
$$

Equation Siddiqi and Glass (1981):

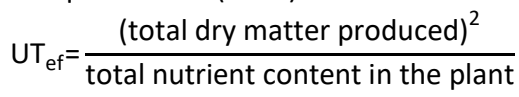

\section{Statistical analyses}

Results were subjected to the variance analysis using software Sisvar Inc., Brazil (Ferreira, 2014). When it was significate, a polynomial regression analysis was proceeded. Linear and quadratic mathematical models were tested to select the one that provided the best data adjustment, based on the magnitude of the regression coefficients significance at $5 \%$ probability by the $t$ test. The maximum points were calculated by deriving the significant equations.

\section{Conclusion}

The growth rate and the relative chlorophyll index in sorghum are not affected by increasing silicon rates 
application on leaves; however, leaf area can increase by up to $23 \%$ with the use of $3.36 \mathrm{~g} \mathrm{~L}^{-1}$ of $\mathrm{Si}$. Physiological parameters are influenced by silicon application, with rates close to $1.68 \mathrm{~g} \mathrm{~L}^{-1}$ of Si leading to the best photosynthetic and stomatal conductance rates. Foliar application of potassium silicate in rates up to $3.36 \mathrm{~g} \mathrm{~L}^{-1}$ of $\mathrm{Si}$ leads to increases of around $30 \%$ in sorghum biomass production.

\section{References}

Ahmed M, Qadeer U, Aslam MA (2011) Silicon application and drought tolerance mechanism of sorghum. Afr J Agric Res 6(3), 594-607.

Alves AF, Carvalho KF, Lima AA, Alves AF, Ferreira TA (2014) Resposta do silício em condições de estresse salino em feijão caupi variedade Gurgéia. Rev Verde Agroeco Desenv Sustentável. 9(5):124-128.

Barbosa Filho MP, Snyder GH, Fageria NK, Datnoff LE, Silva OD (2001) Silicato de cálcio como fonte de silício para o arroz de sequeiro. Rev Bras Ciênc Solo. 25(2):325-330.

Brown PH, Hu H (1998) Phloem boron mobility in diverse plant species. Bot Acta. 111:331-335.

Carvalho MP, Júnior LAZ, Grossi JAS, Barbosa G (2009). Silício melhora produção e qualidade do girassol ornamental em vaso. Ciênc Rural 39(8):2394-2399.

Cessa RMA, Novelino JO, Vitorino ACT, Mauad M (2011) Absorção de fósforo e crescimento do Sorgo em função da aplicação de silício e fósforo em Latossolo Vermelho Distroférrico. Rev Ciênc Agrárias 34(1):135-142.

Cocker KM, Evans DE, Hodson MJ (1998). The amelioration of aluminium toxicity by silicon in higher plants: Solution chemistry or an in planta mechanism?. Physiol Plant 104(4), 608-614.

Crusciol CAC, Soratto RP, Castro GSA, Costa CHMD, Ferrari Neto J (2013) Foliar application of stabilized silicic acid on soybean, common bean, and peanut. Rev Cienc Agron 44(2), 404-410.

Ferreira DF (2014) Sisvar: a guide for its bootstrap procedures in multiple comparisons. Ciênc Agrotec 38(2):109-112.

Fonseca IM, Prado RM, Vidal AA, Nogueira TAR (2009) Efeito da escória, calcário e nitrogênio na absorção de silício e na produção do capim marandu. Bragantia 68(1):221-232.

Galvez L, Clark RB, Gourley LM, Maranville JW (1987) Silicon interactions with manganese and aluminum toxicity in sorghum. J Plant Nutr 10(9-16), 1139-1147.

Gong HJ, Chen KM, Chen GC, Wang SM, Zhang CL (2003) Effects of silicon on growth of wheat under drought. J Plant Nutrition 26(5):1055-1063.

Gong HJ, Chen KM, Zhao ZG, Chen GC, Zhou WJ (2008) Effects of silicon on defense of wheat against oxidative stress under drought at different developmental stages. Biol Plantarum 52(3):592-596.

Hattori T, Inanaga S, Araki H, An P, Morita S, Luxová M, Lux A (2005) Application of silicon enhanced drought tolerance in Sorghum bicolor. Physio Plantarum 123(4):459-466.

Hattori T, Inanaga S, Tanimoto E, Lux A, Luxová M, Sugimoto $Y$ (2003). Silicon-induced changes in viscoelastic properties of sorghum root cell walls. Plant Cell Physiol 44(7), 743749.

Hocking PJ (1980) Redistribution of nutrient elements from cotyledons of two species of annual legumes during germination and seedling growth. Ann Bot 45:383-396.
Kafi M, Rahimi Z (2011) Effect of salinity and silicon on root characteristics, growth, water status, propline contents and ion accumulation of purslane (Portulaca oleracea L.). Soil Sci Plant Nutrition. 57:341-347.

Korndörfer CM, Abdala AL, Bueno ICS (2001) O silício e as gramíneas no cerrado. Rev Notícias 7(1):153-163.

Korndörfer GH (2004). Análise de silício: solo, planta e fertilizante. Viçosa: Instituto de Ciências Agrárias Universidade Federal de Uberlândia.

Lux A, Luxová M, Abe J, Tanimoto E, Hattori T, Inanaga S. (2003) The dynamics of silicon deposition in the sorghum root endodermis. New Phytol 158(3), 437-441.

Lux A, Luxová M, Hattori T, Inanaga S, Sugimoto Y (2002) Silicification in sorghum (Sorghum bicolor) cultivars with different drought tolerance. Physiol Plant 115(1), 87-92.

Ma JF, Yamaji N (2006) Silicon uptake and accumulation in higher plants. Trends Plant Sci 11(8):392-397.

Malavolta E (2006). Manual de nutrição mineral de plantas. São Paulo: Editora Agronômica Ceres.

Matoh T, Kairusmee P, Takahashi E (1986) Salt-induced damage to rice plants and alleviation effect of silicate. Soil Sci Plant Nutrition 32(2):295-304.

Okamoto Y (1970) Physiological studies on the effects of silicic acid upon rice plants: XIII. Effects of silicic acid on the formation of organs and tissues of rice plants. Jpn J Crop Sci 39(2), 151-155.

Oliveira LA, Castro NM (2002) Ocorrência de sílica nas folhas de Curatella americana L. e de Davilla elliptica St. Hill. Rev Horizonte Científico 38:159-170.

Prado RM (2008) Nutrição de plantas. São Paulo: Editora Unesp

Ribas PM (2003) Sorgo: introdução e importância econômica. Sete Lagoas: Embrapa Milho e Sorgo.

Santos Júnior UM, Gonçalves JFC, Feldpausch TR (2006) Growth, leaf nutrient concentration and photosynthetic nutrient use efficiency in tropical tree species planted in degraded areas in central Amazonia. Forest Ecol Manag 226(1-3):299-309.

Santos MC, Junqueira AMR, Sá VGM, Zanúncio JC, Bauch MA, Serrão JE (2012) Efeito do silício em aspectos comportamentais e na história de vida de Tuta absoluta (Meyrick) (Lepidoptera: Gelechiidae). Rev Bras Agropec Sustentável 2(1): 76-88.

Sávio FL, Silva GC, Teixeira IR, Borém A (2011) Produção de biomassa e conteúdo de silício em gramíneas forrageiras sob diferentes fontes de silicato. Semina: Ciênc Agrárias 32(1):103-110.

Siddiqi LM, Glass ADM (1981) Utilization index: a modified approach to the estimation and comparison of nutrient utilization efficiency in plants. J Plant Nutr 4:289-302.

Soil Survey Staff. Keys to Soil Taxonomy (2014) 12 th ed. United States Department of Agriculture Natural Resources Conservation Service, Washington, DC, USA.

Soratto RP, Crusciol CAC, Castro GSA, Costa CHMD, Ferrari Neto J (2012) Leaf application of silicic acid to white oat and wheat. Rev Bras Ciênc Solo 36(5), 1538-1544.

Soundararajan P, Sivanesan I, Jana S, Jeong BR (2014) Influence of silicon supplementation on the growth and tolerance to high temperature in Salvia splendens. Hortic Environ Biotechnol 55(4), 271-279.

Sousa DMG, Lobato E (2004) Cerrado: correção do solo e adubação. 2.ed. Brasília: Embrapa. (in Portuguese) 
Steudle E, Peterson CA (1998) How does water get through roots?. J Exp Bot 49(322), 775-788.

Swiader JM, Chyan, Y, Freiji FG (1994) Genotypic differences in nitrate uptake and utilization efficiency in pumpkin hybrids. J Plant Nutr 17:1687-1699.

Toledo MZ, Amaral Castro GS, Crusciol C, Alexandre C, Soratto RP, Cavariani C, Ishizuka MS, Picoli LB (2012) Silicon leaf application and physiological quality of white oat and wheat seeds. Semina: Ciênc Agrár 1693-1701.

Tripathi DK, Mishra S, Chauhan DK, Tiwari SP, Kumar C (2013) Typological and frequency based study of opaline silica (phytolith) deposition in two common Indian Sorghum L. species. P Natl A Sci India B 83(1), 97-104.

Will S, Eichert T, Fernández V, Möhring J, Müller T, Römheld $\checkmark$ (2011) Absorption and mobility of foliar-applied boron in soybean as affected by plant boron status and application as a polyol complex. Plant Soil 344(1-2):283-293.

Yin L, Wang S, Li J, Tanaka K, Oka M (2013) Application of silicon improves salt tolerance through ameliorating osmotic and ionic stresses in the seedling of Sorghum bicolor. Acta Physiol Plantarum 35(11):3099-3107.

Zheng LY, Guo XS, He B, Sun L, Peng Y, Dong SS, Jing HC (2011) Genome-wide patterns of genetic variation in sweet and grain sorghum (Sorghum bicolor). Genome Biol 12(11):1-14.

Zhu Z, Wei G, Li J, Qian Q, Yu JH (2004) Silicon alleviates salt stress and increases antioxidant enzymes activity in leaves of salt-stressed cucumber (Cucumis sativus L.). Plant Sci 167(3):527-533. 